\title{
Frederick L. Hoffman, LLD (Hon), 1865-1946
}

\author{
Richard A. Brand MD
}

Published online: 28 July 2009

(C) The Association of Bone and Joint Surgeons $(2009$

\begin{abstract}
This biographical sketch on Frederick L. Hoffman corresponds to the historic text, The Classic: A Plan for a More Effective Federal and State Health Administration, available at DOI 10.1007/s11999-0091000-x. The article can also be accessed on the American Journal of Public Health web site at http://www.ajph.org/ cgi/reprint/9/3/161-a.
\end{abstract}

Frederick L. Hoffman (original spelling, Hoffmann) was a leading figure in public health and the role of government in health policy. He was born in Oldenburg, Germany in 1865 [3]. His father died of tuberculosis when he was ten, and several years later he was forced to quit school to apprentice as a shop-boy (which included heavy lifting) [4]. Hoffman was slight of build and neither interested in nor suited for heavy work, and much to the consternation and disgust of his mother, was repeatedly fired from various positions. He was a dreamer, and eventually in 1884 (at the age of 19) a relative loaned him money to go to Cleveland and work for an immigrant shop keeper. The job, similar to those he disliked in Germany, led him to wander south as soon as he saved a bit of money, living as a hobo. He found his way to Georgia, where in 1887 he became a shipping clerk for the Standard Oil Company. There he met his wife-to-be, Ella Hay. Continuing his peripatetic life, he went to Boston to visit a friend, Henry Carruthers, who helped him find a job in Boston collecting premiums for burial insurance policies. The two friends

R. A. Brand ( $\square)$

Clinical Orthopaedics and Related Research, 1600 Spruce Street, Philadelphia, PA 19103, USA

e-mail: dick.brand@clinorthop.org moved to Chattanooga in 1890 to open their own brokerage business. It was during this time he married Ella Hay, with whom he eventually had seven children. However, the still depressed post-Civil War economy in the south did not favor their business, and when the partnership dissolved, Hoffman went to work for the Life Insurance Company of Virginia in their Norfolk office. There he became interested in the social status of African-Americans and wrote, "Vital Statistics of the Negro," published by a Boston journal [1] in which he documented substantially higher industrial death rates in African-Americans than in Caucasians. This paper came to the attention of the Prudential Life Insurance Company, and in 1894 he joined their statistical department in Newark, where he worked for nearly 40 years. He had a continuing interest in the plight of African-Americans in society [5]. The New York Times of February 6, 1926, reported a speech before the national urban league suggesting “...that unfavorable influences on Negro health were "environmental rather than racial"" [3].

Despite his lack of formal training, he conducted substantial research and published widely. According to Sypher (from whom most of this material comes) [3] he published about “...1300 items, including 28 major works of 100 or more pages. And he wrote a huge amount of unpublished material, including his reports to the president of Prudential." He was a founder and board member of public health organizations such as the American Cancer Society and American Tuberculosis Association; he became an associate member of the American Medical Association. He was awarded American citizenship in 1892, and in 1911 Tulane University granted him an honorary doctorate (LLD). He early recognized the dangers of tobacco and, in a large study published in 1915 [2], suggested tobacco was a contributing cause to cancer of the mouth. Other seminal works documenting statistical 
evidence included those related to respiratory diseases in "dusty trades", and malaria. He visited native populations of North and South America and catalogued various traditional remedies.

Hoffman was also interested in national health and pension insurance, issues as relevant today as then. Despite his seemingly liberal views on many public health policies, he believed such plans "fiscally unsound" and "socially unwise" [3]. That is not to say he did not believe in a strong government role for the health of society. In the article we reproduce here he emphasized the distinction in a belief of individual responsibility for physical well-being and that of a societal role:

"...practically all that concerns the health of the individual and his or her own physical well-being, is still considered primarily and essentially a matter of personal concern only...It may then be said that instead of the individual of today being concerned chiefly in the efficient performance of an important but limited state function regarding himself or his family, the modern conception is rather the reverse in that the government or the state is profoundly more interested in the most successful adaptation of each and every individual to his or her environment, be that what it may. Once that this as yet but very imperfectly conceived principle is generally approved, the urgency of a complete remodeling of our federal and state health organizations becomes self-evident."

"There can be no entirely effective Federal or state health administration which continues to ignore the physical facts of individual life and which does not concern itself with the conclusions derived from collective investigations concerning physical progress and physical well-being...Furthermore, and still more lamentable, is the fact that in not even the most advanced countries are such fragmentary data as exist intelligently utilized, but, quite to the contrary, are contemptuously disregarded as needless to the higher requirements of an intelligent policy of government resting upon the declared principle of general welfare."

He proposed three "fundamental principles" for a government role: (1) "...a standardized form of measurements and medical examination..."; (2) "...the accurate and complete registration of all serious illnesses..."; and (3) "...limited state medical service..." Of the latter he noted, "Certain practical difficulties, no doubt, would arise at the outset of such a proposed state medical service, but it is the only alternative to the existing chaotic condition, which, in many respects, is in urgent need of radical reform." It is remarkable this man of no formal education achieved so very much, rose to such prominence, and so presciently proposed what was needed. Nearly a century later we have yet to institute needed reforms, the situation is just as chaotic, and the needs just as urgent. Many of the articles in this month's symposium, "Health Policy Issues in Orthopaedics" address various approaches to these sorts of reforms.

\section{References}

1. Hoffman F. Vital statistics of the Negro. Arena. 1892;29:556-557.

2. Hoffman F. The Mortality from Cancer throughout the World. Newark, NJ: The Prudential Press; 1915.

3. Sypher F. The Rediscovered Prophet: Frederick L. Hoffman (1865-1946). Available at: http://www.cosmos-club.org/web/ journals/2000/sypher.html. Accessed June 25, 2009.

4. Sypher FJ. Frederick L. Hoffman: His Life and Works. Philadelphia, PA: Xlibris; 2002.

5. Wolff MJ. The myth of the actuary: life insurance and Frederick L. Hoffman's race traits and tendencies of the American Negro. Public Health Rep. 2006;121:84-91. 